\title{
Mineral excretion of rats fed on diets containing faba beans (Vicia faba L.) or faba bean fractions
}

\author{
By LUIS A. RUBIO*, GEORGE GRANT, SUSAN BARDOCZ, PETER DEWEY \\ AND A. PUSZTAI† \\ The Rowett Research Institute, Bucksburn, Aberdeen AB2 9SB
}

(Received 18 February 1991-Accepted 22 May 1991)

\begin{abstract}
The effects on faecal mineral excretion of two commercial varieties (local cultivar and Troy cultivar) of raw faba beans (Vicia faba L., minor) meal (VFM) and its fractions have been studied in growing rats. Diets contained local-VFM (dark seed coat) and Troy-VFM (light seed coat) at 474-500 g/ $/ \mathrm{kg}$ diet, hull (VFH) from both varieties at $65 \mathrm{~g} / \mathrm{kg}$ diet, and the insoluble cotyledon residue (VFCR) obtained from the Troy variety at $237 \mathrm{~g} / \mathrm{kg}$ diet. Rats were pair-fed on diets which had been supplemented with amino acids to target requirements and contained similar amounts of zine, manganese, iron and copper. With VFM diets the apparent absorption of $\mathrm{Zn}$ and $\mathrm{Mn}$ was significantly reduced. On the other hand, with hulls the apparent absorption of $\mathrm{Fe}$ was reduced while that of $\mathrm{Cu}$ slightly increased. As the amounts of calcium, phosphorus and magnesium in VFM and VFH diets were higher than in the controls, the increased intake resulted in a significant increase in both the apparent absorption and the faecal excretion of these minerals. The inclusion of VFCR in the diet had no significant effect on the mineral content of faeces. The relatively low concentrations of phytate in the bean seeds of 7.8 and $6.7 \mathrm{~g} / \mathrm{kg}$ for the local and Troy cultivars respectively, could not adequately account for the increased mineral excretion. The results suggest that other seed constituents, possibly the soluble non-starch polysaccharides, may be involved in the elevated loss of $\mathrm{Zn}$ and $\mathrm{Mn}$ in rats fed on diets containing faba bean for extended periods, while some insoluble structural hull components may interfere with the absorption of Fe from the gut.
\end{abstract}

Faba bean (Vicia faba): Faecal mineral excretion: Rat.

Legume crops, particularly faba beans (Vicia faba), peas (Pisum sativum) and lupins (Lupinus sativus), are important protein sources for animal production in Europe. However, a number of nutritional disturbances have been described in animals fed on these materials, particularly when raw legume meals were incorporated in the diet, due to the presence of antinutritional factors. Legumes are also of great interest in human nutrition, particularly in those regions of the world where they constitute the main protein source of the diet (Hellendoorn, 1979). Due to the relatively low cost and the potentially beneficial effects related to their consumption, interest in legume seeds is increasing. Most of the presumed nutritionally advantageous properties of these seeds have been suggested to be associated with carbohydrate fractions. Thus, the most important beneficial effects may be related to altered intestinal transit time and to changes in both carbohydrate and lipid metabolism caused by the presence of fibre (Anderson \& Chen, 1979; Sgarbieri, 1989). The recommendations of the National Advisory Committee on Nutrition Education (1983) in this context were that average daily intake of fibre should be increased from $20 \mathrm{~g}$ to $30 \mathrm{~g}$.

* Present address: Megara Iberica, S.A, 28020 Madrid, Spain.

$\dagger$ For reprints. 
Apart from the presumed cholesterol-lowering effects of legume-based diets (Anderson et al. 1984), vegetable sources of protein may also alter the availability of minerals for rats (Davis et al. 1962; Forbes et al. 1979; Martinez et al. 1985). Although other factors are also likely to be involved, most of the attention has been focused on the phytate content of these materials (O'Dell et al. 1964; Davies \& Nightingale, 1975; Forbes et al. 1984), despite the recognition that fibres in plant-based diets may also alter mineral availability (Anderson \& Chen, 1979; Forbes, 1984). The aim of the present work was to determine the effects of $V$. faba as a legume source on mineral excretion in rats. Since these seeds have previously been shown to affect the availability of zinc and calcium in chickens (Rubio \& Brenes, 1988), V. faba seedmeal and a number of fractions derived from it were tested in order to find out which component is responsible for the effects on intestinal mineral absorption.

\section{MATERIALS AND METHODS \\ Fractionation of the $\mathrm{V}$. faba meal}

$V$. faba insoluble cotyledon residue (VFCR; $158 \mathrm{~g}$ ) was obtained after extraction with stirring of dry faba bean cotyledon meal (VFC; $260 \mathrm{~g}$ ) from the cultivar Troy in phosphate

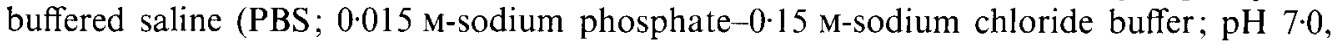
$2 \mathrm{l})$ in the cold for $24 \mathrm{~h}$. The sediment obtained after centrifugation $(20000 \mathrm{~g}, 30 \mathrm{~min})$ was recovered by freeze-drying (VFCR). $V$. faba hulls (VFH) were obtained, after cracking the seeds, by means of an air-classification device.

\section{Animals and diets}

Male rats of the Hooded Lister (Rowett) strain were weaned at $19 \mathrm{~d}$ of age and given a stock diet (Biosure; Special Diets Services, Manea, Cambridgeshire) for $10 \mathrm{~d}$. Rats, matched by weight $(90 \pm \mathrm{l} \mathrm{g})$, were housed singly in metabolism cages based on the design of Schiller (1960) but using glass separators for urine and faeces collection. The amount of diets fed to animals was restricted to a total food consumption of $76.5 \mathrm{~g} /$ rat over the $10 \mathrm{~d}$ period. Distilled water was available $a d$ lib. The animals were weighed daily. Urine and faeces were collected daily and stored at $-20^{\circ}$ until required. Faeces samples were freezedried and ground in a mortar.

The diets (Table 1) were formulated to contain the same amount of protein $(100 \mathrm{~g} / \mathrm{kg})$. With VFM, the diets had to be supplemented with amino acids, including $(\mathrm{g} / \mathrm{kg}$ diet) histidine $0 \cdot 6$, tyrosine $0 \cdot 8$, phenylalanine $1 \cdot 2$, leucine $1 \cdot 0$, isoleucine 1.9 , valine $1 \cdot 7$, tryptophan $0 \cdot 5$, methionine $2 \cdot 4$, to reach target requirements (Coates et al. 1969). The results obtained with the faba-bean diets were compared with the nutritional performance of rats on a lactalbumin (LA) control diet.

Two varieties of faba beans, a locally grown variety with dark seed coats and a cultivar, Troy, with clear seed coats, from Church (Bures) Ltd were used. VFCR from the Troy variety and VHF from both cultivars were included in diets in the same proportion as that in the seed meal. This amount was calculated from their recoveries in the extraction and separation procedures (Table 1).

\section{Chemical analysis}

Minerals. Samples of faeces $(500 \mathrm{mg})$ and diets $(200 \mathrm{mg})$ were digested in $5.5 \mathrm{ml} \mathrm{nitric}$ acid $(4 \mathrm{ml})$-perchloric acid $(1.0 \mathrm{ml})$-sulphuric acid $(0.5 \mathrm{ml})$. Zinc, iron, copper and manganese were determined by atomic absorption spectrophotometry. Calcium and magnesium were analysed colorimetrically by complexing with cresolphthalein (Gitelman, 1967) and eriochrome black T (Gitelman et al. 1966) respectively. Phosphorus was determined by means of the ammonium molybdate metavanadate reaction (Roach, 1965). 
Table 1. Composition of diets and food intake, weight gain, dry body-weight and faecal excretion of rats fed on diets containing Vicia faba meal or its fractions

(Mean values and standard deviations for live weight gain of rats on the different diets over 10 days, and dry body-weights, faecal dry weights and water contents (expressed as means with their standard error of difference (SED)) for four rats)

\begin{tabular}{|c|c|c|c|c|c|c|c|}
\hline Diet $\ldots$ & LA & $\begin{array}{l}\text { Local- } \\
\text { VFM }\end{array}$ & $\begin{array}{l}\text { Troy- } \\
\text { VFM }\end{array}$ & $\begin{array}{l}\text { Local- } \\
\text { VFH }\end{array}$ & $\begin{array}{l}\text { Troy- } \\
\text { VFH }\end{array}$ & VFCR & SED \\
\hline \multicolumn{8}{|l|}{ Ingredients ( $\mathrm{g} / \mathrm{kg}$ diet) } \\
\hline Maize starch & 360 & 26 & - & 295 & 295 & 139 & \\
\hline Potato starch & 100 & 100 & 100 & 100 & 100 & 100 & \\
\hline Glucose & 150 & 150 & 150 & 150 & 150 & 150 & \\
\hline Maize oil & 150 & 150 & 150 & 150 & 150 & 150 & \\
\hline Vitamins + minerals & 100 & 100 & 100 & 100 & 100 & 100 & \\
\hline Silicic acid & $0 \cdot 4$ & $0 \cdot 4$ & $0 \cdot 4$ & 0.4 & 0.4 & 0.4 & \\
\hline Lactalbumin & 140 & - & - & 140 & 140 & 124 & \\
\hline VFM & - & 474 & 500 & - & - & - & \\
\hline VFCR & - & - & - & - & - & 237 & \\
\hline VFH & - & - & - & 65 & 65 & - & \\
\hline Energy $(\mathrm{kJ} / \mathrm{g})$ & $17 \cdot 5$ & $15 \cdot 9$ & $15 \cdot 8$ & $16 \cdot 5$ & $16 \cdot 5$ & $17 \cdot 5$ & \\
\hline $\begin{array}{l}\text { Food intake } \\
\text { (g/10 d per rat) }\end{array}$ & $76 \cdot 5$ & $76 \cdot 5$ & $76 \cdot 5$ & $76 \cdot 5$ & $76 \cdot 5$ & $76 \cdot 5$ & \\
\hline \multicolumn{8}{|l|}{ Live-wt gain $(\mathrm{g} / 10 \mathrm{~d})$ : } \\
\hline Mean & $27 \cdot 6^{a}$ & $17 \cdot 1^{\mathrm{c}}$ & $16 \cdot 2^{\prime}$ & $21 \cdot 3^{\mathrm{b}}$ & $24 \cdot 1^{b}$ & $27 \cdot 3^{4}$ & \\
\hline SD & 0.5 & $0 \cdot 9$ & $0 \cdot 5$ & 0.5 & 0.2 & $0 \cdot 4$ & \\
\hline Dry body-wts (g) & $36 \cdot 1^{4}$ & $30 \cdot 9$ & $30 \cdot 2$ & $33 \cdot 5^{\mathrm{b}}$ & $33 \cdot 7^{\mathrm{b}}$ & $35 \cdot 5^{\mathrm{a}}$ & $1 \cdot 0$ \\
\hline Faecal dry wt (g) & $4 \cdot 1^{\mathrm{a}}$ & $12 \cdot 2^{c}$ & $15 \cdot 8^{d}$ & $7 \cdot 8^{\mathrm{h}}$ & $8 \cdot 2^{b}$ & $5 \cdot 5^{\mathrm{a}}$ & 0.8 \\
\hline Water (g) & $2 \cdot 7^{\mathrm{a}}$ & $13 \cdot 5^{\mathrm{b}}$ & - & - & - & $7 \cdot 8^{\circ}$ & 0.9 \\
\hline
\end{tabular}

i. b. ". " Means in the same row with different superscript letters were significantly different $(P<0.01)$.

LA, lactalbumin control; Local-VFM, locally grown Vicia faba cultivar meal; Troy-VFM, $V$. faba Troy cultivar meal; Local-VFH, hulls from locally grown $V$. faba cultivar; Troy-VFH, hulls from $V$. faba Troy cultivar; VFCR, V. faba insoluble cotyledon residue.

Phytate. Samples obtained with acid-extraction were absorbed by anion-exchange resin and the phytates in the acid eluates from the column were determined colorimetrically after hydrolysis to inorganic phosphate (Harland \& Oberleas, 1986).

Carbohydrates. The carbohydrate composition of the seeds and seed fractions was determined as in Rubio et al. (1991).

Statistical analysis

The results were subjected to analysis of variance. Significant differences between means were determined by using Student's $t$ test (Steel \& Torrie, 1960).

\section{RESULTS}

Growth and performance

As shown in Table 1 , body-weight gain ( $\mathrm{g} / 10 \mathrm{~d}$ per rat) of the animals fed on either VFM or VFH from both cultivars was significantly lower than that of controls (LA). Dry bodyweights of these rats were also significantly lower. In contrast, neither the live nor the dry 
Table 2. Mineral content of diets

(Values are means of four replicates with their standard error of difference (SED))

\begin{tabular}{lccccccc}
\hline \hline Diet* ... & LA & $\begin{array}{c}\text { Local- } \\
\text { VFM }\end{array}$ & $\begin{array}{c}\text { Troy- } \\
\text { VFM }\end{array}$ & $\begin{array}{c}\text { Local- } \\
\text { VFH }\end{array}$ & $\begin{array}{c}\text { Troy- } \\
\text { VFH }\end{array}$ & VFCR & SED \\
\hline Calcium (g/kg) & $4 \cdot 4$ & $7 \cdot 5$ & $6 \cdot 8$ & $6 \cdot 4$ & $6 \cdot 4$ & $5 \cdot 0$ & 1 \\
Phosphorus (g/kg) & $5 \cdot 2$ & $8 \cdot 2$ & $6 \cdot 4$ & $6 \cdot 5$ & $6 \cdot 6$ & $5 \cdot 7$ & 1 \\
Magnesium (g/kg) & $0 \cdot 31$ & $0 \cdot 70$ & $0 \cdot 55$ & $0 \cdot 43$ & $0 \cdot 41$ & $0 \cdot 31$ & 1 \\
Zinc (mg/kg) & 47 & 50 & 45 & 48 & 47 & 46 & 2 \\
Iron (mg/kg) & 54 & 70 & 67 & 55 & 55 & 52 & 3 \\
Copper (mg/kg) & 5 & 12 & 10 & 7 & 7 & 5 & 1 \\
Manganese (mg/kg) & 48 & 54 & 56 & 55 & 55 & 52 & 3 \\
\hline \hline
\end{tabular}

LA, lactalbumin control; Local-VFM, locally grown Vicia faba cultivar meal; Troy-VFM, $V$. faba Troy cultivar meal ; Local-VFH, hulls from locally grown $V$. faba cultivar; Troy-VFH, hulls from $V$. faba Troy cultivar; VFCR, $V$. faba insolubie cotyledon residue.

* For details, see Table 1 and p. 296.

Table 3. Mineral composition and phytate content of Vicia faba seeds

\begin{tabular}{|c|c|c|c|c|}
\hline \multirow[t]{2}{*}{ Cultivar } & \multicolumn{2}{|c|}{ Troy } & \multicolumn{2}{|c|}{ Locally grown } \\
\hline & Cotyledon & Hull & Cotyledon & Hull \\
\hline Calcium $(\mathrm{g} / \mathrm{kg})$ & $0 \cdot 31$ & $3 \cdot 34$ & 0.67 & $3 \cdot 33$ \\
\hline Phosphorus (g/kg) & 3.65 & 0.76 & 5.47 & 1.35 \\
\hline Magnesium (g/kg) & $0 \cdot 39$ & $0 \cdot 88$ & 0.44 & 0.92 \\
\hline Zinc $(\mathrm{mg} / \mathrm{kg})$ & 23 & 13 & 26 & 18 \\
\hline Iron (mg/kg) & 45 & 25 & 62 & 31 \\
\hline Copper $(\mathrm{mg} / \mathrm{kg})$ & nd & nd & nd & nd \\
\hline Manganese $(\mathrm{mg} / \mathrm{kg})$ & 15 & 18 & 11 & 12 \\
\hline Phytate $(\mathrm{g} / \mathrm{kg})$ & $7 \cdot 3$ & $2 \cdot 4$ & $8 \cdot 5$ & 3.4 \\
\hline
\end{tabular}

nd, not determined.

body-weights of VFCR-fed animals were significantly different from control values (Table 1). Animals fed on VFM excreted significantly more faeces, with higher faecal nitrogen and water contents (Table 1).

\section{Mineral excretion}

Because of the widely different mineral contents of the two faba bean cultivars and their fractions not all diets were equalized for all individual minerals (Tables 2 and 3 and Fig. 1). Thus, the amounts of $\mathrm{Ca}, \mathrm{P}$ and $\mathrm{Mg}$ in VFM and VFH diets were generally higher than in the lactalbumin control or VFCR diet, which resulted in higher intakes of these minerals by rats in the appropriate treatment groups. Consequently, faecal losses of $\mathrm{Ca}, \mathrm{P}$ and $\mathrm{Mg}$ tended to be higher with these rats (Fig. 1). However, with the higher intakes their apparent absorption also increased (Fig. 1). In contrast, although the intake of $\mathrm{Zn}, \mathrm{Mn}$, and to some extent $\mathrm{Fe}$ and $\mathrm{Cu}$, was similar in the different treatment groups, the apparent absorption of $\mathrm{Zn}$ and $\mathrm{Mn}$ was significantly depressed in rats fed on VFM diets (Fig. 1 and Table 4). With hulls in the diet (VFH) the apparent absorption of Fe was slightly reduced while that of $\mathrm{Cu}$ (Table 4) was slightly increased (Fig. 1 and Table 4). The dietary inclusion of the cotyledon residue (VFCR) had essentially no effect on the excretion of minerals. 

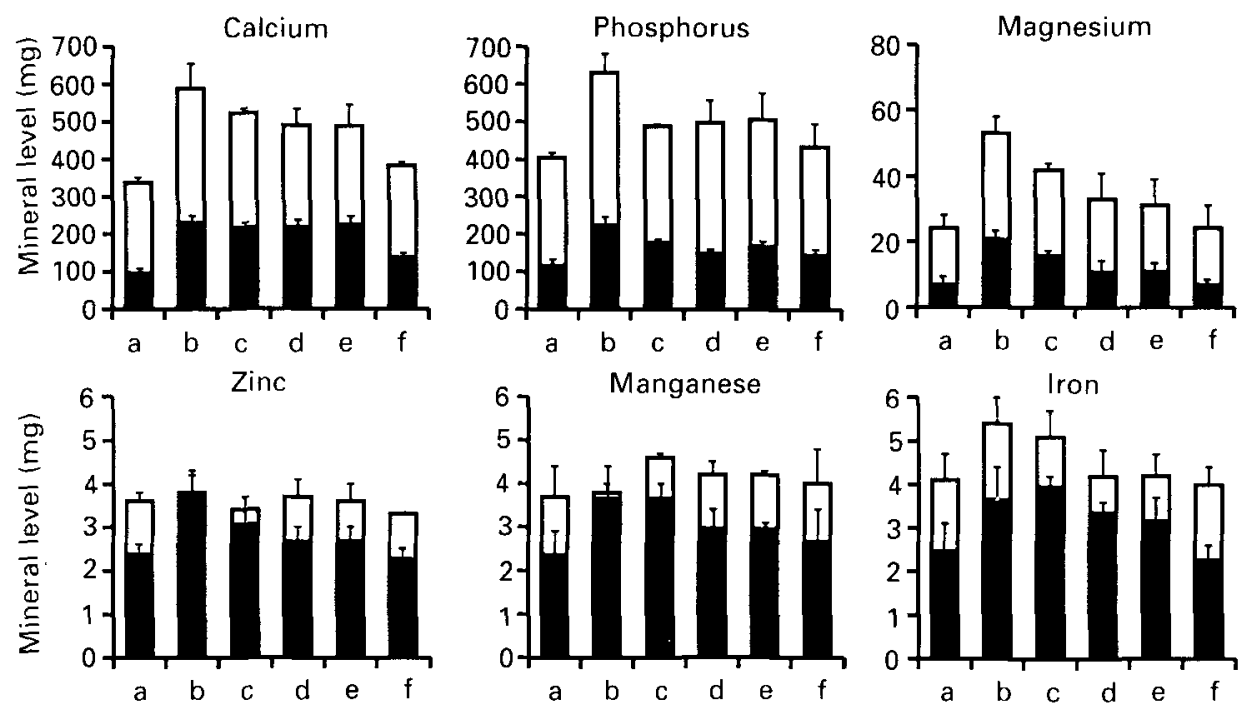

Fig. 1. Apparent absorption (intake - faecal excretion) of minerals by rats fed on diets containing Vicia faba beans and fractions derived from $V$.faba for $10 \mathrm{~d}$. ( $\square$ ), Mineral contents of $76.5 \mathrm{~g}$ of diet and $(\square)$ corresponding mineral outputs in faeces for diets. (a), Lactalbumin control; (b), Local-VFM, locally grown $\boldsymbol{V}$. faba cultivar meal; (c), Troy-VFM, V. faba Troy cultivar meal; (d), Local-VFH, hulls from locally grown $V$. faba cultivar; (e), TroyVFH, hulls from $V$. faba Troy cultivar; (f), VFCR, $V$. faba insoluble cotyledon residue. Values are means and standard deviations represented by vertical bars.

Table 4. Relative amounts of minerals excreted in the faeces ( $\%$ of ingested) of rats fed on diets containing Vicia faba beans or a number of fractions derived from $\mathrm{V}$. faba

(Values are means with their standard error of difference (SED) for four rats)

\begin{tabular}{lccccccc}
\hline \hline Diet* $\ldots$ & LA & $\begin{array}{c}\text { Local- } \\
\text { VFM }\end{array}$ & $\begin{array}{c}\text { Troy- } \\
\text { VFM }\end{array}$ & $\begin{array}{c}\text { Local- } \\
\text { VFH }\end{array}$ & $\begin{array}{c}\text { Troy- } \\
\text { VFH }\end{array}$ & VFCR & SED \\
\hline Calcium & $30^{\mathrm{a}}$ & $41^{\mathrm{bc}}$ & $42^{\mathrm{bc}}$ & $46^{\mathrm{b}}$ & $47^{\mathrm{b}}$ & $37^{\mathrm{ac}}$ & 3 \\
Phosphorus & $30^{\mathrm{a}}$ & $36^{\mathrm{bc}}$ & $37^{\mathrm{c}}$ & $31^{\mathrm{ab}}$ & $34^{\mathrm{ab}}$ & $35^{\mathrm{ab}}$ & 2 \\
Magnesium & $29^{\mathrm{a}}$ & $40^{\mathrm{c}}$ & $39^{\mathrm{a}}$ & $32^{\mathrm{ab}}$ & $36^{\mathrm{bc}}$ & $31^{\mathrm{ab}}$ & 2 \\
Zinc & $66^{\mathrm{a}}$ & $100^{\mathrm{b}}$ & $90^{\mathrm{b}}$ & $74^{\mathrm{a}}$ & $75^{\mathrm{a}}$ & $65^{\mathrm{a}}$ & 3 \\
Iron & $59^{\mathrm{a}}$ & $69^{\mathrm{ab}}$ & $79^{\mathrm{b}}$ & $81^{\mathrm{b}}$ & $76^{\mathrm{b}}$ & $58^{\mathrm{a}}$ & 4 \\
Copper & $99^{\mathrm{a}}$ & $94^{\mathrm{a}}$ & $100^{\mathrm{a}}$ & $70^{\mathrm{b}}$ & $75^{\mathrm{b}}$ & $100^{\mathrm{a}}$ & 3 \\
Manganese & $66^{\mathrm{a}}$ & $86^{\mathrm{b}}$ & $88^{\mathrm{b}}$ & $71^{\mathrm{a}}$ & $73^{\mathrm{a}}$ & $71^{\mathrm{a}}$ & 4 \\
\hline \hline
\end{tabular}

a. b. Means in the same row with different superscript letters were significantly different $(P<0 \cdot 05)$.

LA, lactalbumin control; Local-VFM, locally grown Vicia faba cultivar meal; Troy-VFM, $V$. faba Troy cultivar meal; Local-VFH, hulls from locally grown $V$. faba cultivar; Troy-VFH, hulls from $V$. faba Troy cultivar; VFCR, $V$. faba insoluble cotyledon residue.

* For details, see Table 1 and p. 296.

\section{DISCUSSION}

There are some indications that the availability of $\mathrm{Zn}$ in rats (Martinez et al. 1985) and that of $\mathrm{Ca}$ and $\mathrm{Zn}$ in chickens is reduced by feeding faba beans or faba bean fractions (Rubio \& Brenes, 1988). Significant disturbances in growth, protein and nucleic acid metabolism and in the immune response occur in mice fed on $V$. faba as the only source of protein in the diet, and some of these were totally or partially counteracted by supplementing the diets with additional $\mathrm{Zn}$ (Macarulla, 1989). 
In the present study the excretion of $\mathrm{Ca}, \mathrm{P}, \mathrm{Mg}, \mathrm{Zn}, \mathrm{Fe}$ and $\mathrm{Mn}$, expressed as a percentage of the amounts ingested, was significantly increased in animals fed on diets containing VFM (Table 4). However, because of the higher $\mathrm{Ca}, \mathrm{P}$ and $\mathrm{Mg}$ contents of VFM and VFH diets this was partly the result of a higher intake of these minerals by rats in the appropriate treatment groups. In contrast, as the amounts of $\mathrm{Zn}, \mathrm{Mn}$ and $\mathrm{Fe}$ were similar in all diets, the reduction of the apparent absorption of $\mathrm{Zn}$, and to some extent $\mathrm{Mn}$, by rats fed on diets based on VFM was highly significant. Although the results were similar for both cultivars, the extent of faecal losses were higher with the local dark-coat variety of $V$. faba in most instances. The reason for this was unclear.

The effects of using vegetable-protein sources on mineral availability in animals have been extensively studied since the early sixties. Thus, $\mathrm{Zn}$ availability in chicks and rats fed on soya-bean protein has been shown to be low (Forbes, 1984). With divalent metals such as $\mathrm{Zn}, \mathrm{Ca}$ and $\mathrm{Mg}$, it is usually the phytate content of the vegetable materials that is claimed to be largely responsible for their increased excretion in faeces. Several studies have indicated that minimum molar ratios of phytate: $\mathrm{Zn}$ of $15-20$ in the diet are needed to lower the availability of the minerals and to cause growth depression in young rats (Davies \& Olpin, 1979). The amounts of phytates in the seeds used in the present study are $6.7 \mathrm{~g} / \mathrm{kg}$ for the Troy cultivar and $7.8 \mathrm{~g} / \mathrm{kg}$ for the local cultivar (Table 3). Thus, phytate: $\mathrm{Zn}$ molar ratios in the diets are 6.3 for the local-VFM and 6.9 for VFM from the Troy variety. The Ca content of the diet has also been reported to be important in this context (Forbes et al. 1983; Forbes 1984). The [Ca $\times$ phytate]:Zn molar ratio in the diets used in the present study was $1 \cdot 2-1 \cdot 3$ for local-VFM and Troy-VFM, which is far from the value 3 considered as critical in rats (Davies et al. 1985). The values of mineral excretion were very similar with both VFM despite their different $P$ content. Similar considerations apply to diets containing the hulls. Moreover, in studies in vitro with wholemeals or bran from which the phytate was removed by extraction with acid or phytase (EC 3.1.3.8), an increased binding of metals was found instead of the expected decrease (Reinhold et al. 1976). These considerations have led several investigators to the conclusion that other factors apart from the phytate content of the seeds are likely to be playing an important role in the high mineral excretion induced by vegetarian diets (Anderson \& Chen, 1979; Rubio et al. 1990, 1991).

The importance of fibre intake on intestinal digestibility of the different nutrients in the diet is now generally accepted. Some fractions of the fibre, particularly pectins, can bind cations due to free carboxyl groups of uronic acids (Anderson \& Chen, 1979; Eastwood \& Kay, 1979; Kahn et al. 1987). Uronic acids constitute the main portion of the soluble, unavailable carbohydrates in faba beans (Pritchard et al. 1973), and previously reported values are very similar to those determined in the seeds used in the present study (Table 5). Indeed, at least $2 \%$ of the non-starch polysaccharides (NSP) of these seeds are soluble in PBS buffer. In agreement with the present findings (Table 1) and previous findings with chickens fed on faba beans (Rubio et al. 1990), this fraction has considerable water-holding capacity and gel-forming properties which may delay intestinal transit (Anderson \& Chen, 1979). Accordingly, it is possible that the soluble NSP fraction of the seed, together with phytate, could play an important role in the blockage of intestinal absorption of divalent minerals and in other effects observed in animals fed on faba bean (Rubio et al. 1989, 1990, 1991). With the exception of $\mathrm{Fe}$ and $\mathrm{Ca}$, the significant effect on mineral excretion appears to be confined to the soluble fraction of the cotyledon, as the hulls or the insoluble residue have only slight effects (Table 4). This agrees with the findings of Weingartner et al. (1979) that soya-bean hulls, which contained three to four times more phytate than faba bean hulls, had no significant effects on the bioavailability of $\mathrm{Zn}$ for rats.

As regards Fe excretion, the main effect is probably attributed to the hull fraction of the 
Table 5. Carbohydrate composition $(\mathrm{g} / \mathrm{kg}$ ) of Vicia faba meal (Troy cultivar) and its fractions

\begin{tabular}{lcccc}
\hline \hline $\begin{array}{l}\text { Amount in seed } \\
(\mathrm{g} / \mathrm{kg}) \ldots\end{array}$ & $\begin{array}{c}\text { Whole seed } \\
1000\end{array}$ & $\begin{array}{c}\text { Cotyledon } \\
870\end{array}$ & $\begin{array}{c}\text { VFCR } \\
520\end{array}$ & $\begin{array}{c}\text { Hulls } \\
130\end{array}$ \\
\hline Rhamnose & $2 \cdot 2$ & $1 \cdot 0$ & - & $6 \cdot 2$ \\
Fucose & $1 \cdot 6$ & $1 \cdot 0$ & - & $3 \cdot 4$ \\
Arabinose & $19 \cdot 6$ & $23 \cdot 0$ & $33 \cdot 2$ & $16 \cdot 9$ \\
Xylose & $13 \cdot 4$ & $5 \cdot 5$ & $8 \cdot 6$ & $71 \cdot 0$ \\
Mannose & $1 \cdot 2$ & $0 \cdot 7$ & - & $2 \cdot 6$ \\
Galactose & $10 \cdot 8$ & $18 \cdot 0$ & $24 \cdot 4$ & $22 \cdot 9$ \\
Glucose & $83 \cdot 0$ & $27 \cdot 0$ & $40 \cdot 0$ & $450 \cdot 2$ \\
Uronic acids & $35 \cdot 0$ & $30 \cdot 0$ & $36 \cdot 5$ & $112 \cdot 4$ \\
Total NSP & $166 \cdot 0$ & $106-0$ & $143 \cdot 0$ & $686 \cdot 0$ \\
Starch & $421 \cdot 0$ & $486 \cdot 0$ & $683 \cdot 0$ & $37 \cdot 0$ \\
Free sugars & $42 \cdot 0$ & $51 \cdot 0$ & $1 \cdot 0$ & $12 \cdot 0$ \\
\hline \hline
\end{tabular}

NSP, non-starch polysaccharides; VFCR, insoluble cotyledon residue.

seeds. Gilooly et al. (1983) reported a significant inverse correlation between polyphenol content of the diet and Fe absorption in humans. The low extractability of the proteins in the $V$. faba seeds used in the present study in comparison with other legume seeds (at least $25 \%$ of the protein remains in the residue after extraction with neutral buffer for $24 \mathrm{~h}$; Rubio et al. 1991) suggests the presence of significant amounts of tannins. Faba beans grown in the UK are reported to contain 7.5-20.0 g tannins $/ \mathrm{kg}$ (Griffiths \& Jones, 1977), most of them confined to the hull fraction of the seed. As the values for Fe excretion were similar in animals fed on the whole faba meal or the hulls of the seed, it is probable that the hull tannins are the main factor responsible for this interference in the absorption of Fe from the gut.

The authors are very grateful to $\mathrm{Mr}$ W. R. Humphries for the help with mineral determinations and to $\mathrm{Mr} \mathrm{Xu}$ Pin for assistance with phytate analysis, and to both for useful discussions. The Postdoctoral Grant from the Spanish Ministry of Education and Science to L. A. R. is gratefully acknowledged. A.P. is indebted to the Leverhulme Trust for an Emeritus Fellowship and to The Royal Society of Edinburgh for the Auber Bequest Award. This collaborative work is a part of a European FLAIR Concerted Action Programme (No. 9) coordinated by A.P. with financial support from the Commission of European Communities.

\section{REFERENCES}

Anderson, J. W. \& Chen, W.-J. L. (1979). Plant fibre, carbohydrate and lipid metabolism. American Journal of Clinical Nutrition 32, 346-363.

Anderson, J. W., Story, L., Sieling, B., Chen, W.-J. L., Petro, M. S. \& Story, J. (1984). Hypocholesterolemic effects of oat-bran or bean intake for hypercholesterolemic men. American Journal of Clinical Nutrition $\mathbf{4 0}$, 1146-1 I55.

Coates, M. E., O’Donoghue, P. N., Payne, P. R. \& Ward, R. J. (1969). In Laboratory Animal Handbooks. 2. Laboratory Standards for Laboratory Rats and Mice, p. 15. London: Laboratory Animals Ltd.

Davies, N. T., Carswell, A. J. P. \& Mills, C. F. (1985). The effect of variation in dietary calcium intake on the phytate- $\mathrm{Z}_{\mathrm{n}}$ interaction in rats. In Trace Elements in Man and Animals - TEMA 5, pp. $456-457$ [C. F. Mills, I. Bremner and J. K. Chesters, editors]. Farnham Royal, Slough: CAB.

Davies, N. T. \& Nightingale, R. (1975). The effects of phytate on intestinal absorption of zinc, and whole-body retention of $\mathrm{Zn}$, copper, iron and manganese in rats. British Journal of Nutrition 34, 243-258.

Davies, N. T. \& Olpin, S. E. (1979). Studies on the phytate:zine molar contents in diets as a determinant of $\mathrm{Zn}$ availability to young rats. British Journal of Nutrition 41, 591-603. 
Davis, P. N., Norris, L. C. \& Kratzer, F. H. (1962). Interference of soybean proteins with the utilization of trace minerals. Journal of Nutrition 77, 217-223.

Eastwood, W. A. \& Kay, R. M. (1979). A hypothesis for the action of dietary fibre along the gastrointestinal tract. American Journal of Clinical Nutrition 32, 364-367.

Forbes, R. M. (1984). Use of laboratory animals to define physiological functions and bioavailability of zinc. Federation Proceedings 43, 2835-2839.

Forbes, R. M., Erdman, J. W. Jr, Parker, H. M., Kondo, H. \& Ketelsen, S. M. (1983). Bioavailability of zinc in coagulated soy protein (tofu) to rats and effect of dietary calcium at a constant phytate:zinc ratio. Journal of Nutrition 113, 205-210.

Forbes, R. M., Parker, H. M. \& Erdman, J. W. Jr (1984). Effects of dietary phytate, calcium and magnesium levels on zinc bioavailability to rats. Journal of Nutrition 114, 1421-1425.

Forbes, R. M., Weingartner, K. E., Parker, H. M., Bell, R. R. \& Erdman, J. W. Jr (1979). Bioavailability to rats of zinc, magnesium and calcium in casein-, egg- and soya protein-containing diets. Journal of Nutrition 109 , 1652-1660.

Gillooly, M., Bothwell, T. H., Torrance, J. D., MacPhail, A. P., Derman, D. P., Bezboda, W. R., Mills, W. \& Charlton, R. W. (1983). The effects of organic acids, phytates and polyphenols on the absorption of iron from vegetables. British Journal of Nutrition 49, 331 342.

Gitelman, H. J. (1967). An improved automated procedure for the determination of calcium in biological specimens. Analytical Biochemistry 18, 521-531.

Gitelman, H. J., Hurt, C. \& Lutwak, L. (1966). An automated spectrophotometric method for magnesium analysis. Analytical Biochemistry 14, $106-120$.

Griffiths, D. W. \& Jones, D. I. H. (1977). Cellulase inhibition by tannins in the testa of field beans (Vicia faba). Journal of the Science of Food and Agriculture 28, 983-989.

Harland, B. F. \& Oberleas, D. (1986). Anion-cxchange method for determination of phytate in foods: collaborative study. Journal of the Association of Official Analytical Chemists 69, 667-670.

Hellendoorn, E. W. (1979). Beneficial physiological activity of leguminous seeds. Qualitas Plantarum. Plant Foods for Human Nutrition 29, 227-244.

Kahn, A., Vohra, P. N. \& Kratzer, F. H. (1987). The effect of protein level and dietary guar gum and pectin on copper and zinc utilization in chicks. Nutrition Reports International 36, 193-200.

Macarulla, M. T. (1989). Influencia de la ingestion de dietas de Vicia faba L. con diferentes niveles de zinc sobre el estado nutritivo y la respuesta inmune del raton. (Influence of the ingestion of Vicia faba $\mathrm{L}$. diets of different zine contents on the nutritional state and the immune response of the mouse.) Tesis Doctoral, Universidad de Navarra, Pamplona, Spain.

Martinez, J. A., Barcina, Y. \& Larralde, J. (1985). Interrelationships between zinc supply and protein source in young and adult rats. Nutrition Reports International 32,1037-1046.

National Advisory Committee on Nutrition Education (1983). Proposals for Nutritional Guidelines for Health Education in Britain. London: Health Education Council.

O’Dell, B. L., Johe, J. M. \& Savage, J. E. (1964). Zinc availability in the chick as affected by phytate, calcium and ethylenediaminetetraacetate. Poultry Science 43, 415-419.

Pritchard, P. J., Dryburgh, E. A. \& Wilson, B. J. (1973). Carbohydrates of spring and winter field beans (Vicia faba L.). Journal of the Science of Food and Agriculture 24, 663668.

Reinhold, J. G., Faradji, B., Abadi, P. \& Ismail-Beigi, F. (1976). Decreased absorption of calcium, magnesium, zinc and phosphorus by humans due to increased fiber and phosphorus consumption as wheat bread. Journal of Nutrition 106, 493-503.

Roach, A. G. (1965). Application of the Technicon AutoAnalyzer equipment to the routine determination of calcium and phosphorus in animal feedstufts. Automation in Analytical Chemistry, pp. 137-144. Basingstoke: Technicon Instruments Co. Ltd.

Rubio, L. A. \& Brenes, A. (1988). Plasma mineral concentrations in growing chickens fed diets containing raw and autoclaved faba beans (Vicia faba L.) and faba bean fractions. Nutrition Reports International 38, 609-6I9.

Rubio, L. A., Brenes, A. \& Castano, M. (1989). Histological alterations of the pancreas and the intestinal tract produced by raw faba bean (Vicia faba L., minor) diets in growing chicks. British Poultry Science 30, 15-28.

Rubio, L. A., Brenes, A. \& Castano, M. (1990). The utilization of raw and autoclaved faba beans (Vicia faba L., minor) and faba bean fractions in diets for growing broiler chickens. British Journal of Nutrition 63, 419-433.

Rubio, L. A., Grant, G., Bardocz, S., Dewey, P. \& Pusztai, A. (1991). Nutritional response of growing rats to faba beans (Vicia faba, L., minor) and faba bean fractions. Brifish Journal of Nutrition 66, 533-542.

Schiller, K. (1960). Ein Stoffwechselkafig für Raten (A metabolism cage for rats). Zeitschrift für Tierphysiologie, Tierernahrung und Futtermittelkunde 15, 305-308.

Sgarbieri, V. C. (1989). Nutritive value of beans. In Nutritional Value of Cereal Products, Beans and Starches, pp. 132-199 [G. H. Bourne, editor]. Basel, Switzerland: Karger.

Steel, R. G. D. \& Torrie, J. H. (1960). Principles and Procedures of Statistics. New York: McGraw-Hill.

Weingartner, K. E., Erdman, J. W., Parker, H. M. \& Forbes, R. M. (1979). Effect of soybean hull upon the bioavailability of zinc and calcium from soy flour-based diets. Nutrition Reports International 19, $223-231$. 